\title{
BMJ
}

\section{Mortality among residents of shelters, rooming houses, and hotels in Canada: 11 year follow-up study}

\author{
Stephen W Hwang, research scientist, ${ }^{1}$ associate rofessor, ${ }^{2}$ Russell Wilkins, senior research analyst, ${ }^{3}$ adjunct \\ professor, ${ }^{4}$ Michael Tjepkema, senior research analyst, ${ }^{5}$ MHSc candidate, ${ }^{6}$ Patricia J O'Campo, director, \\ professor, ${ }^{6,7}$ James R Dunn, chair in applied public health, ${ }^{1}$ associate professor ${ }^{6,8,9,10}$
}

${ }^{1}$ Centre for Research on Inner City Health, Keenan Research Centre, Li Ka Shing Knowledge Institute, St Michael's Hospital, Toronto, ON, Canada

${ }^{2}$ Division of General Internal Medicine, Department of

Medicine, University of Toronto, Toronto

${ }^{3}$ Health Information and Research Division, Statistics Canada, Ottawa

${ }^{4}$ Department of Epidemiology and Community Medicine, University of Ottawa, Ottawa

${ }^{5}$ Health Information and Research Division, Statistics Canada,

Toronto

${ }^{6}$ Dalla Lana School of Public Health, University of Toronto Toronto

${ }^{7}$ Department of Population, Reproductive and Family Health, Johns Hopkins Bloomberg School of Public Health, Baltimore, MD, USA

${ }^{8}$ Department of Geography and Programme in Planning, University of Toronto, Toronto

${ }^{9}$ Successful Societies Program, Canadian Institute for Advanced Research, Toronto

${ }^{10}$ Department of Health, Aging and Society, McMaster University, Hamilton, ON

Correspondence to: S W Hwang Centre for Research on Inner City Health, St. Michael's Hospital, 30 Bond Street, Toronto, ON, Canada M5B 1W8

hwangs@smh.toronto.on.ca.

Cite this as: $B M J$ 2009;339:b4036 doi:10.1136/bmi.b4036

\section{ABSTRACT}

Objective To examine mortality in a representative nationwide sample of homeless and marginally housed people living in shelters, rooming houses, and hotels.

Design Follow-up study.

Setting Canada 1991-2001.

Participants 15100 homeless and marginally housed people enumerated in 1991 census.

Main outcome measures Age specific and age standardised mortality rates, remaining life expectancies at age 25 , and probabilities of survival from age 25 to 75 . Data were compared with data from the poorest and richest income fifths as well as with data for the entire cohort

Results Of the homeless and marginally housed people, 3280 died. Mortality rates among these people were substantially higher than rates in the poorest income fifth, with the highest rate ratios seen at younger ages. Among those who were homeless or marginally housed, the probability of survival to age 75 was $32 \%$ (95\% confidence interval $30 \%$ to $34 \%$ ) in men and $60 \%$ (56\% to $63 \%$ ) in women. Remaining life expectancy at age 25 was 42 years ( 42 to 43 ) and 52 years ( 50 to 53), respectively. Compared with the entire cohort, mortality rate ratios for men and women, respectively, were 11.5 (8.8 to 15.0) and 9.2 (5.5 to 15.2 ) for drug related deaths, 6.4 (5.3 to 7.7 ) and 8.2 (5.0 to 13.4) for alcohol related deaths, 4.8 (3.9 to 5.9) and 3.8 (2.7 to 5.4) for mental disorders, and 2.3 (1.8 to 3.1) and 5.6 (3.2 to 9.6) for suicide. For both sexes, the largest differences in mortality rates were for smoking related diseases, ischaemic heart disease, and respiratory diseases.

Conclusions Living in shelters, rooming houses, and hotels is associated with much higher mortality than expected on the basis of low income alone. Reducing the excessively high rates of premature mortality in this population would require interventions to address deaths related to smoking, alcohol, and drugs, and mental disorders and suicide, among other causes.

\section{INTRODUCTION}

Many studies have shown that low socioeconomic status, as measured by income, education, or occupation, is strongly associated with higher mortality. ${ }^{12}$ These differences are believed to exist, at least in part, because income, education, and occupation are markers for the material conditions of everyday life. Another such marker might be the type of housing in which a person lives. At the extreme end of the spectrum are homeless people sleeping rough on the street. More often, homeless people live in shelters, hostels, and missions. ${ }^{3}$ Somewhat less disadvantaged individuals, who are sometimes referred to as being "marginally housed," might live in low cost collective dwellings such as YMCA/YWCA facilities, rooming and lodging houses, and single room occupancy hotels, where each resident has a bedroom and shared access to bathroom facilities. ${ }^{45}$ Individuals with limited housing options might also live in motels, sometimes with rent subsidised by welfare agencies. These housing situations can be important indicators of socioeconomic deprivation beyond that which can be determined on the basis of income alone.

Previous research on mortality among individuals living in settings consistent with severe disadvantage has focused primarily on homeless people. These studies have found high levels of excess mortality among the homeless compared with the general population. Most of these studies have been limited to homeless people in a single city, most notably Philadelphia, ${ }^{6}$ Boston, ${ }^{7}$ New York City, ${ }^{8}$ Copenhagen, ${ }^{9}$ Stockholm, ${ }^{10}$ Toronto, ${ }^{11} 12$ and Montreal. ${ }^{13}$ Additional studies have reported mortality rates in specific subgroups of homeless individuals, such as those with HIV infection living in San Francisco, ${ }^{14}$ those with schizophrenia living in Sydney, Australia, ${ }^{15}$ and United States military veterans with mental illness. ${ }^{16}$ Little information is available on mortality rates in a nationwide representative sample of homeless people or on mortality rates among those who are homeless and living in shelters compared with those who are marginally housed and living in other categories of collective dwellings.

Our main goal was to determine age and sex specific mortality rates, causes of death, and probabilities of survival to various ages in a representative nationwide sample of homeless and marginally housed people living in shelters, rooming houses, and hotels in Canada. To overcome some of the limitations of previous 
Table 1|Census respondents, study cohort, linkage rate, deaths ascertained, and person years at risk, non-institutional population aged 25 and over at baseline, 1991*

\begin{tabular}{|c|c|c|c|c|c|}
\hline Sex and category & Census respondents & Study cohort & Linkage rate (\%) & No of deaths & Person years at risk \\
\hline \multicolumn{6}{|l|}{ Both sexes } \\
\hline Entire cohort & 3576500 & 2735200 & 76 & 260820 & 27618420 \\
\hline Shelters, rooming houses, hotels & 41800 & 15100 & 36 & 3280 & 141660 \\
\hline Shelters & 5700 & 1500 & 26 & 338 & 14130 \\
\hline Rooming houses & 19200 & 7800 & 41 & 1864 & 72380 \\
\hline Hotels & 16900 & 5800 & 34 & 1078 & 55150 \\
\hline Poorest income fifth & 715400 & 470400 & 66 & 75229 & 4589150 \\
\hline Richest income fifth & 715100 & 587400 & 82 & 36593 & 6033060 \\
\hline \multicolumn{6}{|l|}{ Men } \\
\hline Entire cohort & 1738000 & 1358400 & 78 & 153552 & 13580340 \\
\hline Shelters, rooming houses, hotels & 29700 & 10500 & 35 & 2359 & 97690 \\
\hline Shelters & 3900 & 900 & 23 & 219 & 8390 \\
\hline Rooming houses & 13500 & 5500 & 40 & 1267 & 50670 \\
\hline Hotels & 12300 & 4100 & 33 & 873 & 38640 \\
\hline Poorest income fifth & 306000 & 197300 & 64 & 35839 & 1895900 \\
\hline Richest income fifth & 372300 & 309900 & 83 & 23638 & 3161140 \\
\hline \multicolumn{6}{|l|}{ Women } \\
\hline Entire cohort & 1838500 & 1376800 & 75 & 107268 & 14038080 \\
\hline Shelters, rooming houses, hotels & 12100 & 4600 & 38 & 921 & 43970 \\
\hline Shelters & 1800 & 600 & 33 & 119 & 5750 \\
\hline Rooming houses & 5700 & 2400 & 42 & 597 & 21710 \\
\hline Hotels & 4600 & 1700 & 36 & 205 & 16510 \\
\hline Poorest income fifth & 409400 & 273000 & 67 & 39390 & 2693250 \\
\hline Richest income fifth & 342700 & 277500 & 81 & 12955 & 2871930 \\
\hline
\end{tabular}

research, which included a narrow set of comparison groups - typically only the general population, we also compared mortality rates among various categories of homeless and marginally housed people with rates in people in the poorest and richest fifths of income of the general population. By using these comparison groups, we sought to detect excess mortality associated with homelessness and marginal housing beyond that associated with low income alone.

\section{METHODS}

We used data from the Canadian census mortality follow-up study, which tracked mortality in a $15 \%$ sample of the adult population of Canada. ${ }^{17}$ People were eligible for the study cohort if they were aged 25 or older and a usual resident of Canada on the day of the census (4 June 1991), were not a long term resident of an institution such as a prison, hospital, or nursing home, and had been selected for census enumeration with a detailed "long form" questionnaire. About 3.6 million people met these criteria. The long form questionnaire was administered to one in five private households and to all people living in non-institutional collective dwellings, including the following types of collective dwellings serving homeless and marginally housed individuals: shelters and hostels for the homeless, missions, and YMCA/YWCA facilities ("shelters"); rooming and lodging houses ("rooming houses"); and hotels, motels, and tourist homes ("hotels"). For
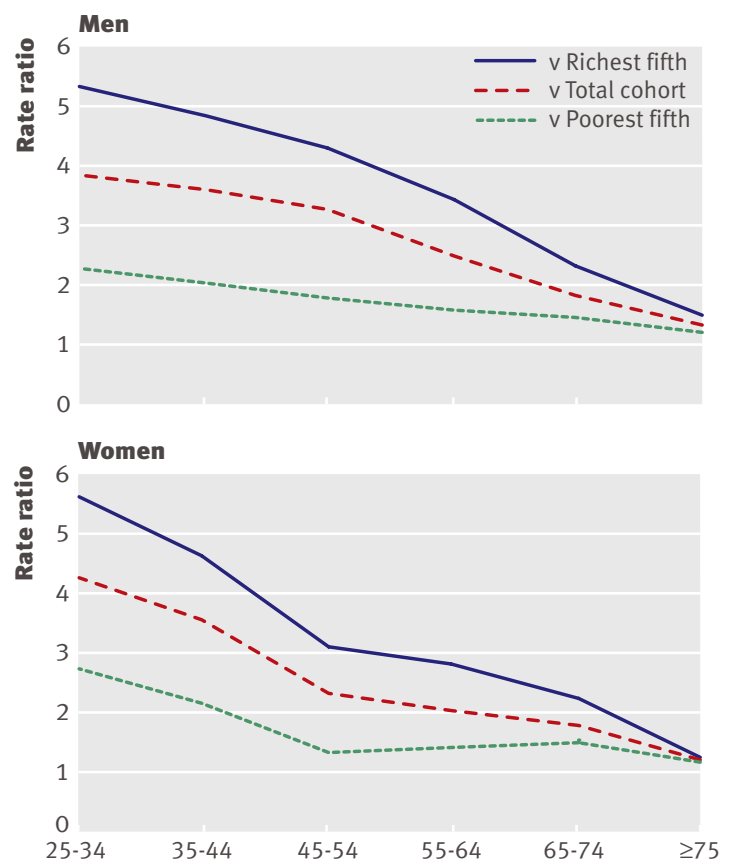

Age at baseline (years)

Fig 1| Mortality rate ratios for men and women living in shelters, rooming houses, and hotels compared with entire cohort and poorest and richest income fifths 
Table 2 |Demographic and socioeconomic characteristics of entire cohort, cohort members living in shelters, rooming houses, and hotels, and all census respondents living in shelters, rooming houses, and hotels, by sex, at baseline, 1991. Figures are column percentages unless stated otherwise

\begin{tabular}{|c|c|c|c|c|c|c|}
\hline \multirow[b]{2}{*}{ Category } & \multicolumn{3}{|c|}{ Men } & \multicolumn{3}{|c|}{ Women } \\
\hline & $\begin{array}{l}\text { Entire study } \\
\text { cohort }\end{array}$ & $\begin{array}{l}\text { Cohort members } \\
\text { in shelters, etc }\end{array}$ & $\begin{array}{l}\text { All census respondents } \\
\text { in shelters, etc }\end{array}$ & $\begin{array}{l}\text { Entire study } \\
\text { cohort }\end{array}$ & $\begin{array}{l}\text { Cohort members } \\
\text { in shelters, etc }\end{array}$ & $\begin{array}{l}\text { All census respondents } \\
\text { in shelters, etc }\end{array}$ \\
\hline No of people & 1358400 & 10500 & 29700 & 1376800 & 4600 & 12100 \\
\hline Age $25-44$ & 53 & 47 & 50 & 56 & 43 & 45 \\
\hline Age 45-64 & 32 & 39 & 36 & 28 & 29 & 28 \\
\hline Age $\geq 65$ & 15 & 14 & 14 & 16 & 28 & 27 \\
\hline Married or common law & 79 & 11 & 13 & 69 & 21 & 23 \\
\hline Education less than high school graduation & 35 & 54 & 52 & 35 & 49 & 50 \\
\hline Employed (any occupation) & 72 & 43 & 45 & 58 & 45 & 42 \\
\hline Poorest two income adequacy fifths & 34 & 80 & 79 & 39 & 82 & 84 \\
\hline Major source of income from government transfers & 16 & 44 & 41 & 21 & 47 & 46 \\
\hline Visible minority & 7 & 7 & 8 & 8 & 6 & 9 \\
\hline Aboriginal & 4 & 5 & 6 & 4 & 6 & 7 \\
\hline Born outside Canada & 21 & 16 & 15 & 21 & 14 & 15 \\
\hline Any activity limitation & 11 & 30 & 23 & 10 & 28 & 24 \\
\hline
\end{tabular}

purposes of brevity, we use the term "shelters, rooming houses, and hotels" to refer to these three categories of collective dwellings. For the 1991 census, no attempt was made to enumerate homeless people sleeping outside, and these individuals were not included in this study.

The electronic 1991 census database did not contain names, which were needed for ascertainment of mortality. To obtain names, census records were linked to tax filer data from 1990 and 1991 with probabilistic matching on the basis of dates of birth and postal codes of the individual and his or her spouse or common law partner (if any), as previously described. ${ }^{17}$ Deaths in the cohort were ascertained by linkage of census records to the Canadian mortality database with probabilistic methods described elsewhere. ${ }^{1819}$ Ascertainment of deaths in the cohort followed for mortality was estimated to be about $97 \% .{ }^{17}$

Data obtained from the 1991 census long form included marital status, education, occupation, income, ethnic origins, Aboriginal status, place of birth, place of residence, and self reported limitation in activity. Data obtained from the Canadian mortality database included date of death and underlying cause of death. Cause of death was coded according to ICD-9 (international classification of diseases, ninth revision) for deaths occurring in 1991-9 and ICD-10 (10th revision) for deaths occurring in 2000-1. Causes of death were grouped by ICD-9 chapter, categories within chapters, and by risk factors (smoking related, alcohol related, drug related, or amenable to medical intervention) (see appendix A on bmj.com). ${ }^{2021}$

To construct income adequacy fifths, we determined the total pre-tax income from all sources for each household or unattached individual. For each applicable family size and community size group we calculated the ratio of total income to the 1991 low income cut-off from Statistics Canada. The population was then ranked according to this ratio, and income fifths were determined within each census metropolitan area, census agglomeration, or rural area.

For each member of the cohort, we calculated person days of follow-up from the day of the census (4 June 1991) to the date of death or the last day of the study period (31 December 2001). Person days of follow-up were divided by 365.25 to obtain person years at risk. We used mortality rates specific for age, sex, income fifth, and collective dwelling by five year age groups to calculate age standardised mortality rates, using the cohort population structure (person years at risk), both sexes together, as the standard population. Corresponding 95\% confidence intervals for age standardised mortality rates were calculated by using previously described methods. ${ }^{22}$
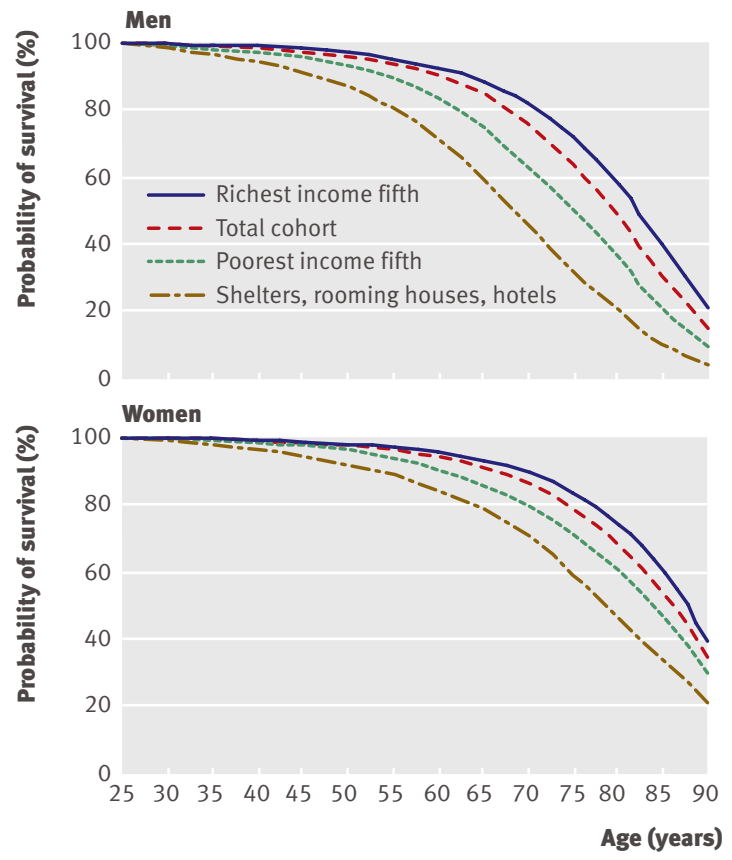

Fig 2 | Probability of survival for men and women conditional on survival to age 25 
Table $3 \mid$ Deaths and age standardised mortality rates per 100000 person years at risk for entire cohort, poorest and richest income fifths, and those living in shelters, rooming houses, and hotels, Canada, 1991-2001*

\begin{tabular}{|c|c|c|c|c|c|c|c|c|}
\hline & \multicolumn{2}{|r|}{ Entire cohort } & \multicolumn{2}{|r|}{ Poorest fifth } & \multicolumn{2}{|c|}{ Richest fifth } & \multicolumn{2}{|c|}{ Shelters, rooming houses, hotels } \\
\hline & Deaths & Rate $(95 \% \mathrm{Cl})$ & Deaths & Rate $(95 \% \mathrm{Cl})$ & Deaths & Rate $(95 \% \mathrm{Cl})$ & Deaths & Rate $(95 \% \mathrm{Cl})$ \\
\hline \multicolumn{9}{|l|}{ Men } \\
\hline Total & 153552 & 1229 (1223 to 1235$)$ & 35839 & 1650 (1633 to 1668$)$ & 23638 & 981 (967 to 995$)$ & 2359 & 2467 (2365 to 2573 ) \\
\hline \multicolumn{9}{|c|}{ Age (years): } \\
\hline $25-34$ & 4481 & 115 (111 to 118$)$ & 1142 & 193 (182 to 204) & 595 & 82 (76 to 89 ) & 112 & 440 (366 to 530$)$ \\
\hline $35-44$ & 8122 & 219 (214 to 224$)$ & 1779 & $392(374$ to 411$)$ & 1371 & 163 (155 to 172$)$ & 194 & 787 (684 to 906$)$ \\
\hline $45-54$ & 14804 & 590 (581 to 600$)$ & 2915 & 1089 (1050 to 1129$)$ & 3739 & 445 (431 to 459$)$ & 411 & 1911 (1734 to 2106) \\
\hline $55-64$ & 31674 & 1701 (1682 to 1720$)$ & 7413 & 2666 (2605 to 2728 ) & 6298 & 1225 (1195 to 1256$)$ & 695 & 4214 (3912 to 4540$)$ \\
\hline $65-74$ & 50359 & 4289 (4251 to 4326) & 10735 & 5321 (5221 to 5422) & 6504 & 3314 (3234 to 3396) & 526 & 7698 (7060 to 8393 ) \\
\hline$\geq 75$ & 44112 & 10721 (10621 to 10823$)$ & 11855 & 11913 (11700 to 12130$)$ & 5131 & 9478 (9218 to 9745$)$ & 421 & 13933 (12 626 to 15 376) \\
\hline \multicolumn{9}{|l|}{ Women } \\
\hline Total & 107268 & 703 (699 to 707$)$ & 39390 & 884 (874 to 894$)$ & 12955 & 592 (582 to 603$)$ & 921 & $1260(1166$ to 1361$)$ \\
\hline \multicolumn{9}{|c|}{ Age (years): } \\
\hline $25-34$ & 2449 & $58(56$ to 60$)$ & 734 & 90 (84 to 97$)$ & 302 & 44 (39 to 49 ) & 27 & 247 (169 to 361) \\
\hline $35-44$ & 5368 & 140 (137 to 144$)$ & 1321 & 231 (219 to 244$)$ & 913 & 107 (101 to 115$)$ & 46 & 495 (371 to 661$)$ \\
\hline $45-54$ & 8264 & 352 (344 to 359$)$ & 1951 & $616(590$ to 644$)$ & 1955 & $263(252$ to 275$)$ & 64 & 816 (639 to 1043$)$ \\
\hline $55-64$ & 14726 & 897 (882 to 911 ) & 4324 & 1292 (1254 to 1332) & 2332 & 643 (617 to 670$)$ & 99 & 1799 (1476 to 2192) \\
\hline $65-74$ & 29871 & 2273 (2248 to 2299) & 10134 & 2718 (2665 to 2772 ) & 3209 & 1815 (1753 to 1879 ) & 172 & 4038 (3470 to 4698 ) \\
\hline$\geq 75$ & 46590 & 6665 (6605 to 6726$)$ & 20926 & 6926 (6832 to 7022 ) & 4244 & 6456 (6264 to 6654$)$ & 513 & 7894 (7164 to 8699 ) \\
\hline
\end{tabular}

${ }^{*}$ Reference population (person years at risk) for age standardisation was taken from total cohort age distribution (5 year age groupings).

Mortality rate ratios and rate differences were used to compare age standardised mortality rates for those living in shelters, rooming houses, and hotels with those in the poorest income fifth, the richest income fifth, and the entire cohort. Mortality rate ratios and rate differences were also calculated separately for each of the subcategories of shelters, rooming houses, and hotels compared with the entire cohort.

We used the actuarial method ${ }^{23}$ to calculate life tables for each sex and income fifth and for different housing categories after transforming age from age at baseline to age at the beginning of each year of followup. Deaths and person years at risk were calculated separately for each year or partial year of follow-up, then pooled by age at the beginning of each year of follow-up, before the calculation of the life tables. Life tables were used to construct survival curves and to determine probability of survival to age 75 , contingent on survival to age 25 .

\section{RESULTS}

Table 1 shows the linkage rate for residents of shelters, rooming houses, and hotels combined and for each category separately. In total, $36 \%$ of the population living in those types of collective dwellings were successfully matched to the name file, resulting in 15100 cohort members followed for mortality, of whom 3280 had died by the end of the follow-up period, during 141660 person years at risk. Among the three categories of non-institutional collective dwellings studied, rooming houses had the highest linkage rate $(41 \%)$ and shelters had the lowest linkage rate $(26 \%)$.

Table 2 shows that, despite the lower linkage rates, the demographic and socioeconomic profile of cohort members living in shelters, rooming houses, and hotels was similar to that of all the census respondents living in those types of collective dwellings. Table 2 also compares the baseline characteristics of cohort members living in shelters, rooming houses, and hotels with the entire cohort. For cohort members living in shelters, rooming houses, and hotels compared with the entire cohort, men were somewhat more likely to be middle aged (45-64), while women were more likely to be older $(\geq 65)$. Compared with the entire cohort, for both men and women, those living in shelters, rooming houses, and hotels were far less likely to have been married and were less likely to have completed a high school education or to have been born outside Canada. As expected, the income distribution of those residing in shelters, rooming houses, and hotels in 1991 differed from the entire cohort. In the entire cohort, only $34 \%$ of men and $39 \%$ of women were in the poorest two fifths, while among those living in shelters, rooming houses, and hotels the corresponding figures were $80 \%$ and $82 \%$. In the entire cohort, $72 \%$ of men and $58 \%$ of women were employed compared with $43 \%$ of men and $45 \%$ of women living in shelters, rooming houses, and hotels.

Table 3 presents age standardised mortality rates per 100000 person years for men and women in the entire cohort, the poorest and richest income fifths, and those living in shelters, rooming houses, and hotels. Figure 1 shows mortality rate ratios for men and women (see also appendix B on bmj.com). In all comparisons rate ratios were higher at younger than at older ages. Rate ratios were highest for shelters, rooming houses, and hotels compared with the richest income fifth-with rate ratios for both men and 
Table 4|Remaining life expectancy at age 25 and expected survivors from ages 25 to 75 , for entire cohort, those living in shelters, rooming houses, and hotels, and for poorest and richest income fifths, by sex, Canada, 1991-2001 (95\% confidence interval in parentheses)

\begin{tabular}{|c|c|c|}
\hline Category & Men & Women \\
\hline \multicolumn{3}{|c|}{ Remaining life expectancy at age 25 (years) } \\
\hline Total, entire cohort & $52.6(52.6$ to 52.7$)$ & $59.0(58.9$ to 59.1$)$ \\
\hline Shelters, rooming houses, hotels & $42.3(41.6$ to 42.9$)$ & $51.6(50.4$ to 52.7$)$ \\
\hline Shelters & $39.2(37.0$ to 41.5$)$ & $50.6(47.5$ to 53.7$)$ \\
\hline Rooming houses & $41.4(40.5$ to 42.3$)$ & $49.7(48.0$ to 51.4$)$ \\
\hline Hotels & $44.3(43.4$ to 45.3$)$ & 53.8 (51.9 to 55.7$)$ \\
\hline Poorest income fifth & $48.4(48.3$ to 48.6$)$ & $56.4(56.3$ to 56.5$)$ \\
\hline Richest income fifth & $55.3(55.2$ to 55.4$)$ & $60.7(60.5$ to 60.8$)$ \\
\hline \multicolumn{3}{|c|}{ Expected survivors from ages 25 to 75 (\%) } \\
\hline Total, entire cohort & $64.0(63.8$ to 64.2$)$ & 79.0 (78.8 to 79.2$)$ \\
\hline Shelters, rooming houses, hotels & 32.1 (30.2 to 33.9) & $59.6(56.0$ to 63.1$)$ \\
\hline Shelters & 27.0 (21.1 to 32.9$)$ & 51.3 (40.8 to 61.9) \\
\hline Rooming houses & $30.6(28.0$ to 33.2$)$ & 53.9 (48.9 to 58.9$)$ \\
\hline Hotels & 35.2 (32.3 to 38.2$)$ & $69.4(63.5$ to 75.3$)$ \\
\hline Poorest income fifth & $50.6(50.1$ to 51.1$)$ & 71.5 (71.0 to 71.9$)$ \\
\hline Richest income fifth & 72.4 (72.0 to 72.8$)$ & 83.8 (83.4 to 84.2$)$ \\
\hline
\end{tabular}

women exceeding 5 at ages 25-34 and well over 4 at ages 35-44. Even when compared with the poorest income fifth, rate ratios were 2 or more at those ages for both men and women. In all comparisons, rate ratios converged toward 1 at ages 75 and over.

Figure 2 shows the probability of survival to various ages (conditional on survival to age 25) for men and women in the entire cohort, the poorest and richest income fifths, and those living in shelters, rooming houses, and hotels. For both men and women, the survival curves were considerably more rectangular for the richest fifth and for the entire cohort compared with the poorest fifth or with those living in shelters, rooming houses, and hotels, reflecting a more favourable mortality pattern.

Figure 3 shows the probabilities of survival to age 75 obtained from the life table analyses. Men living in shelters, rooming houses, and hotels had the lowest probability of survival to age $75(32.1 \%, 95 \%$ confidence interval $30.2 \%$ to $33.9 \%$ ). This was 19 percentage points lower than the probability of survival to age 75 for the poorest fifth $(50.6 \%, 50.1 \%$ to $51.1 \%)$ and 40 percentage points lower than for the richest fifth $(72.4 \%, 72.0 \%$ to $72.8 \%)$. For women, the differences between the groups were notably smaller. For women living in shelters, rooming houses, and hotels, the probability of survival to age $75(59.6 \%, 56.0 \%$ to $63.1 \%$ ) was 12 percentage points less than for the poorest fifth $(71.5 \%, 71.0$ to 71.9$)$, and 24 percentage points less than for the richest income fifth $(83.8 \%, 83.4 \%$ to $84.4 \%)$.

Table 4 shows life expectancy at age 25 . The results are presented for the same four groups plus the three subcategories of the shelter, rooming house, and hotel population. For both men and women, remaining life expectancy was much lower for the combined category of shelters, rooming houses, and hotels compared with the richest income fifth, the entire cohort, or the poorest income fifth. Among the subcategories, it was lowest for people living in shelters and rooming houses, followed by people living in hotels.

For men, remaining life expectancy in the combined shelter, rooming house, and hotel category ( 42.3 years, 41.6 to 42.9 ) was 10 years lower than in the entire cohort, 13 years lower than in the richest income fifth, and six years lower than in the poorest income fifth. For men in the subcategory of shelters, remaining life expectancy (39.2 years, 37.0 to 41.5 ) was another three years lower than for the combined category. For women, remaining life expectancy in the combined shelter, rooming house, and hotel category (51. 6 years, 50.4 to 52.7 ) was seven years lower than in the entire cohort, nine years lower than in the richest income fifth, and five years lower than in the poorest income fifth. For women in the subcategory of rooming houses, remaining life expectancy ( 49.7 years, 48.0 to 51.4) was another two years lower than for the combined category.

We also analysed cause specific mortality. Age standardised mortality rates for the total cohort, the poorest and richest income fifths, and those living in shelters, rooming houses, and hotels in 1991 are presented in appendix C (on bmj.com), while tables 5 (men) and 6 (women) and figure 4 show the rate ratios and rate differences for the entire cohort compared with those living in shelters, rooming houses, and hotels. Compared with the entire cohort, rate ratios for both sexes were higher for mental disorders (4.8 and 3.8 for men and women, respectively), cirrhosis of the liver (3.7 and 5.6), and external causes of death (3.3 and 3.7). Among the external causes, rate ratios for men were particularly higher for homicide (11.3) and poisoning (10.3), while rate ratios for women were highest for suicide (5.6) and all other external causes of death (4.2). For men, the rate ratio was also higher for deaths caused by diseases of the blood and blood forming organs (4.6). For both men and women, rate ratios were higher for deaths related to drugs (11.5 and 9.2 , respectively) and alcohol (6.4 and 8.2). For both men and women, the largest rate differences (per

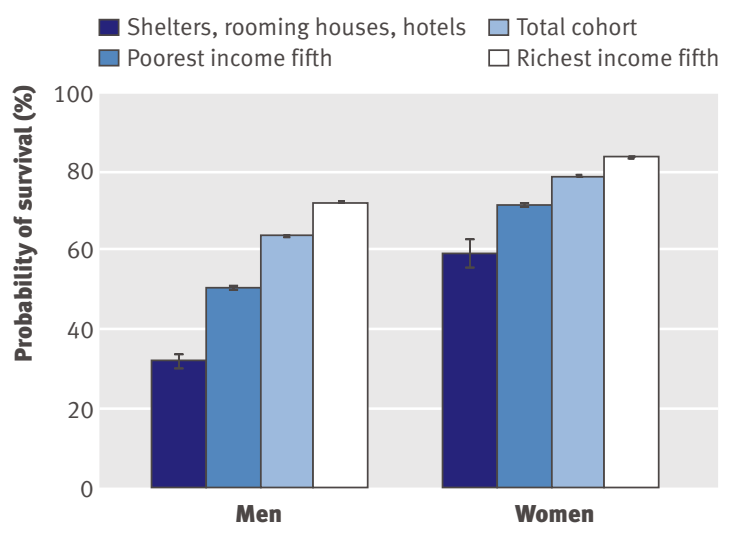

$\overline{\text { Fig } 3 \mid \text { Probability of survival to age } 75 \text {, conditional on survival }}$ to age 25 
Table $5 \mid$ Mortality rate ratios and rate differences* (per 100000 person years at risk), by major causes of death, comparing men living in shelters, rooming houses, and hotels $†$ with men in entire cohortł, Canada, 1991-2001

\begin{tabular}{|c|c|c|}
\hline Cause & Ratio $(95 \% \mathrm{Cl})$ & Difference $(95 \% \mathrm{Cl})$ \\
\hline Total, all causes of death & $2.01(1.92$ to 2.09$)$ & $1237.8(1134.6$ to 1341.0$)$ \\
\hline Infectious diseases & 2.80 (2.07 to 3.78$)$ & 30.8 (16.3 to 45.3$)$ \\
\hline Cancer & $1.56(1.44$ to 1.70$)$ & 219.1 (168.9 to 269.4$)$ \\
\hline Trachea, bronchus, and lung & $1.91(1.67$ to 2.18$)$ & $107.2(77.2$ to 137.3$)$ \\
\hline Intestine and rectum & $1.39(1.08$ to 1.78$)$ & $18.7(1.8$ to 35.7$)$ \\
\hline Oesophagus and stomach & $1.22(0.86$ to 1.74$)$ & $5.7(-5.4$ to 16.7$)$ \\
\hline Pancreas & $1.19(0.75$ to 1.86$)$ & $3.4(-6.3$ to 13.1$)$ \\
\hline Prostate & $0.95(0.69$ to 1.31$)$ & $-2.5(-17.3$ to 12.3$)$ \\
\hline Urinary system & $1.27(0.85$ to 1.90$)$ & $5.9(-5.2$ to 17.0$)$ \\
\hline Lymphatic tissue and leukaemia & $0.90(0.62$ to 1.31$)$ & $-3.6(-15.7$ to 8.5$)$ \\
\hline Other cancer & $2.18(1.86$ to 2.55$)$ & 85.9 (60.8 to 111.0$)$ \\
\hline Endocrine system diseases & $2.01(1.58$ to 2.56$)$ & $38.4(19.8$ to 57.0$)$ \\
\hline Diabetes mellitus & $1.75(1.31$ to 2.34$)$ & 23.1 (7.4 to 38.7$)$ \\
\hline Other endocrine & $3.12(2.01$ to 4.84$)$ & $15.4(5.4$ to 25.4$)$ \\
\hline Blood and blood forming organs & $4.59(2.67$ to 7.87$)$ & 14.1 (4.3 to 23.9 ) \\
\hline Mental disorders & $4.82(3.93$ to 5.92$)$ & 80.1 (59.2 to 101.0$)$ \\
\hline Nervous system diseases & $1.93(1.47$ to 2.54$)$ & $28.8(12.5$ to 45.0$)$ \\
\hline Circulatory system diseases & $1.71(1.59$ to 1.84$)$ & $328.3(269.1$ to 387.6$)$ \\
\hline Ischaemic heart disease & $1.63(1.48$ to 1.80$)$ & 182.4 (137.0 to 227.7$)$ \\
\hline Heart failure & $1.74(1.24$ to 2.46$)$ & 17.1 (3.3 to 30.8$)$ \\
\hline Cerebrovascular disease & $1.87(1.55$ to 2.25$)$ & 64.5 (38.8 to 90.1$)$ \\
\hline Other circulatory diseases & $1.82(1.53$ to 2.17$)$ & 64.5 (39.8 to 89.1$)$ \\
\hline Respiratory system diseases & $2.56(2.26$ to 2.90$)$ & 175.6 (139.5 to 211.6$)$ \\
\hline Pneumonia & $2.30(1.82$ to 2.91$)$ & 44.5 (25.9 to 63.2$)$ \\
\hline Bronchitis, emphysema, and asthma & $2.92(2.49$ to 3.42$)$ & 118.7 (90.0 to 147.4$)$ \\
\hline Other respiratory system diseases & $1.75(1.18$ to 2.61$)$ & 12.3 (0.9 to 23.8 ) \\
\hline Digestive system diseases & 3.07 (2.58 to 3.65$)$ & $87.9(65.0$ to 110.7$)$ \\
\hline Cirrhosis of liver & $3.66(2.83$ to 4.75$)$ & 37.3 (23.9 to 50.7$)$ \\
\hline Other digestive system diseases & $2.78(2.20$ to 3.50$)$ & 50.5 (32.1 to 69.0$)$ \\
\hline Genitourinary system diseases & 1.51 (1.01 to 2.26$)$ & $10.6(-2.1$ to 23.4$)$ \\
\hline Musculoskeletal system diseases & $2.52(1.29$ to 4.94$)$ & $5.7(-0.7$ to 12.1$)$ \\
\hline Ill defined conditions & 5.08 (4.01 to 6.43$)$ & 55.9 (39.2 to 72.6$)$ \\
\hline External causes & $3.34(2.92$ to 3.81$)$ & 158.4 (128.0 to 188.8$)$ \\
\hline Motor vehicle & $1.68(1.09$ to 2.60$)$ & $9.3(-0.6$ to 19.2$)$ \\
\hline Suicide & $2.33(1.76$ to 3.07$)$ & 29.5 (15.0 to 43.9$)$ \\
\hline Falls & $3.06(2.23$ to 4.21$)$ & 26.5 (13.9 to 39.0 ) \\
\hline Homicide & 11.29 (7.21 to 17.69$)$ & 18.4 (9.0 to 27.8 ) \\
\hline Poisoning & 10.34 (7.37 to 14.50$)$ & 30.2 (18.6 to 41.8 ) \\
\hline Other external causes & 4.15 (3.21 to 5.38 ) & $44.6(29.2$ to 59.9$)$ \\
\hline Other and unknown§ & $2.00(0.98$ to 4.07$)$ & $4.0(-1.7$ to 9.8$)$ \\
\hline Smoking related & 2.39 (2.18 to 2.62$)$ & 281.3 (236.5 to 326.1$)$ \\
\hline Alcohol related & 6.35 (5.25 to 7.69$)$ & $80.8(62.2$ to 99.4$)$ \\
\hline Drug related & 11.50 (8.79 to 15.04$)$ & 48.3 (33.6 to 63.0) \\
\hline Amenable to medical intervention ( 875 years) & $3.16(2.72$ to 3.68$)$ & 113.1 (88.1 to 138.1$)$ \\
\hline
\end{tabular}

$100000)$ were for smoking related diseases (281 and 88 , respectively), ischaemic heart disease (182 and 105), respiratory diseases (176 and 61), and deaths amenable to medical intervention (113 and 55).

\section{DISCUSSION}

Homeless and marginally housed individuals living in shelters, rooming houses, or hotels have significantly higher mortality rates than individuals with incomes in the lowest fifth of the distribution. The probability that a 25 year old living in shelters, rooming houses, or hotels would survive to age 75 was only $32 \%$ for men and $60 \%$ for women compared with $51 \%$ and $72 \%$, respectively, in the lowest income fifth. To put this in context, men living in shelters, rooming houses, or hotels had about the same probability of surviving to age 75 as men in the general population of Canada in 1921 or men in Laos in 2006 (see appendix D on bmj.com) ${ }^{2425}$ Women had about the same probability of surviving to age 75 as women in the general population of Canada in 1956 or women in Guatemala in 2006.

Our study, while consistent with previous studies showing excess mortality among people living in shelters, provides new information on disparities in the life expectancy of those living in shelters and those living in other categories of marginal housing. Compared with the entire cohort, life expectancy was shorter by 13 years for men and eight years for women living in shelters; 11 and nine years, respectively, for those living in rooming houses; and eight and five years, respectively, for those living in hotels.

\section{Other studies}

Most previous studies provided only age specific relative risks of death or standardised mortality ratios for homeless individuals in a single city. ${ }^{6-13}$ By contrast, we present survival curves and life expectancy estimates with a comparatively high level of precision based on 3280 deaths ascertained over an 11 year follow-up period among 15100 people enumerated in shelters, rooming houses, and hotels across Canada. Perhaps the only previous study to estimate life expectancy among people living in shelters and other categories of marginal housing was based on much smaller samples in single cities - 39 deaths among 103 shelter users in Oxford and 104 deaths among 927 residents of bed and breakfasts and bedsits in Brighton. ${ }^{26}$

\section{Implications}

A large part of the premature mortality in people living in shelters, rooming houses, and hotels was potentially avoidable. Many excess deaths were attributable to diseases related to alcohol and smoking and to violence and injuries, much of which might have been related to substance misuse. There were also many excess deaths related to mental disorders and suicides. Other research suggests that expanding the implementation of recent innovations in supported housing programmes for people with addictions and mental illness ${ }^{27}$ could be instrumental in reducing the number of excess deaths. Enhanced availability of treatment for substance misuse and smoking cessation programmes for homeless and marginally housed people could also play an important role in reducing disparities in mortality. ${ }^{28}$ 
Table 6 | Mortality rate ratios and rate differences* (per 100000 person years at risk), by major causes of death, comparing women living in shelters, rooming houses, and hotels $\dagger$ with women in entire cohortł, Canada, 1991-2001

\begin{tabular}{|c|c|c|}
\hline Cause & Ratio $(95 \% \mathrm{Cl})$ & Difference $(95 \% \mathrm{Cl})$ \\
\hline Total, all causes of death & 1.79 (1.66 to 1.94$)$ & 556.7 (459.3 to 654.1$)$ \\
\hline Infectious diseases & 1.37 (0.56 to 3.38$)$ & $2.7(-6.2$ to 11.5$)$ \\
\hline Cancer & 1.38 (1.18 to 1.62$)$ & 93.0 (39.7 to 146.3$)$ \\
\hline Trachea, bronchus, and lung & 1.73 (1.26 to 2.36$)$ & $37.8(9.6$ to 65.9$)$ \\
\hline Intestine and rectum & $1.67(1.12$ to 2.51$)$ & $20.6(-0.1$ to 41.2$)$ \\
\hline Oesophagus and stomach & $1.48(0.70$ to 3.15$)$ & $4.4(-5.8$ to 14.6$)$ \\
\hline Pancreas & $0.73(0.29$ to 1.82$)$ & $-3.5(-12.2$ to 5.2$)$ \\
\hline Female breast & 1.58 (1.11 to 2.24$)$ & $26.4(1.2$ to 51.7$)$ \\
\hline Uterus, ovary, adnexa & 1.25 (0.71 to 2.20$)$ & $5.5(-10.1$ to 21.0$)$ \\
\hline Urinary system & 0.76 (0.27 to 2.12$)$ & $-1.7(-7.3$ to 3.8$)$ \\
\hline Lymphatic tissue and leukaemia & 1.26 (0.72 to 2.22$)$ & $5.4(-9.4$ to 20.2$)$ \\
\hline Other cancer & $0.98(0.64$ to 1.49$)$ & $-0.9(-18.6$ to 16.9$)$ \\
\hline Endocrine system diseases & 2.39 (1.70 to 3.38$)$ & $33.7(13.8$ to 53.7$)$ \\
\hline Diabetes mellitus & 2.44 (1.66 to 3.59$)$ & $27.2(9.4$ to 45.0$)$ \\
\hline Other endocrine & 2.23 (1.04 to 4.79$)$ & $6.6(-2.5$ to 15.7$)$ \\
\hline Blood and blood forming organs & 1.45 (0.34 to 6.22$)$ & $1.3(-4.9$ to 7.6$)$ \\
\hline Mental disorders & 3.78 (2.67 to 5.35$)$ & 42.6 (22.4 to 62.9$)$ \\
\hline Nervous system diseases & 2.24 (1.52 to 3.29$)$ & $25.2(7.7$ to 42.8$)$ \\
\hline Circulatory system diseases & $1.61(1.42$ to 1.83$)$ & 153.4 (101.8 to 204.9) \\
\hline Ischaemic heart disease & $1.80(1.52$ to 2.13$)$ & $105.3(65.2$ to 145.4$)$ \\
\hline Heart failure & 1.41 (0.88 to 2.26$)$ & $6.4(-3.9$ to 16.7$)$ \\
\hline Cerebrovascular disease & 1.25 (0.94 to 1.67$)$ & $14.5(-5.9$ to 34.8$)$ \\
\hline Other circulatory diseases & 1.57 (1.15 to 2.14$)$ & $27.2(4.1$ to 50.3$)$ \\
\hline Respiratory system diseases & 2.14 (1.67 to 2.75$)$ & $60.9(32.3$ to 89.5$)$ \\
\hline Pneumonia & 2.16 (1.43 to 3.25$)$ & $21.2(5.0$ to 37.4$)$ \\
\hline Bronchitis, emphysema, and asthma & 2.40 (1.70 to 3.40$)$ & $36.1(14.5$ to 57.8$)$ \\
\hline Other respiratory system diseases & 1.39 (0.66 to 2.91$)$ & $3.6(-5.9$ to 13.0$)$ \\
\hline Digestive system diseases & $2.92(2.11$ to 4.04$)$ & $51.4(25.9$ to 76.9$)$ \\
\hline Cirrhosis of liver & $5.63(3.31$ to 9.56$)$ & 28.7 (10.1 to 47.4$)$ \\
\hline Other digestive system diseases & 2.10 (1.41 to 3.14$)$ & $22.7(5.3$ to 40.0$)$ \\
\hline Genitourinary system diseases & 1.43 (0.79 to 2.58$)$ & $5.1(-5.0$ to 15.3$)$ \\
\hline Musculoskeletal system diseases & $1.63(0.72$ to 3.65$)$ & $3.2(-3.5$ to 10.0$)$ \\
\hline IIl defined conditions & 2.09 (0.96 to 4.55$)$ & $8.5(-4.2$ to 21.2$)$ \\
\hline External causes & $3.68(2.74$ to 4.95$)$ & $75.6(44.7$ to 106.4$)$ \\
\hline Suicide & 5.59 (3.24 to 9.64$)$ & $26.3(8.8$ to 43.9$)$ \\
\hline Falls & 1.65 (0.89 to 3.08$)$ & $6.0(-3.4$ to 15.4$)$ \\
\hline Other external causes & 4.24 (2.80 to 6.42$)$ & $43.3(19.7$ to 66.8$)$ \\
\hline Other and unknown§ & $0.99(0.23$ to 4.33$)$ & $0.0(-4.9$ to 4.8$)$ \\
\hline Smoking related & 2.03 (1.63 to 2.54$)$ & 87.7 (49.7 to 125.7$)$ \\
\hline Alcohol related & $8.20(5.03$ to 13.38$)$ & 36.5 (16.0 to 57.0$)$ \\
\hline Drug related & 9.17 (5.54 to 15.18$)$ & 32.3 (13.8 to 50.9$)$ \\
\hline Amenable to medical intervention ( 875 years) & $1.82(1.37$ to 2.43$)$ & 54.5 (19.0 to 85.6$)$ \\
\hline
\end{tabular}

* Rate ratios and rate differences based on age standardised mortality rates (per 100000 person years at risk). †Shelters, rooming houses, and hotels include homeless shelters and hostels, missions, YWCA/YMCAs, rooming and lodging houses, hotels, motels, and tourist homes.

$\ddagger$ Reference population (person years at risk) for age standardisation taken from total cohort age distribution ( 5 year age groupings).

§Includes deaths from complications of pregnancy $(n=10)$, diseases of skin $(n=122)$, congenital anomalies $(n=152)$, perinatal related causes $(n=2)$, unknown ( 213 deaths ascertained from tax filer data only).

\section{Limitations}

Our study has certain limitations, most of which should result in underestimation of the excess mortality risks associated with homelessness and marginal housing. Firstly, and most importantly, only people who were enumerated by the census and linked to tax filer data could be part of the study cohort. The 1991 census failed to enumerate $3.4 \%$ of the Canadian population; missed individuals were more likely to be young, mobile, have low incomes, and be of Aboriginal ancestry. ${ }^{29}$ Relatively low linkage rates of $26-41 \%$ among residents of shelters, rooming houses, and hotels presumably reflect the fact that many such individuals would not have filed a tax return or remained for long at the same address. We speculate that mortality might have been higher among those who could not be linked to a tax filer record; if so, our data would underestimate the true mortality rate among people living in shelters, rooming houses, and hotels. Nonetheless, it was reassuring that the socioeconomic characteristics of the homeless and marginally housed men and women whom we were able to link to tax filer data and follow for mortality were similar to the characteristics of all homeless and marginally housed individuals who were enumerated by the census. Secondly, we did not include homeless people sleeping rough on the street because they were not enumerated by the 1991 census. Previous studies have shown that these individuals have extremely high mortality rates, even higher than those of shelter residents, ${ }^{30}$ and in Canada they are more likely to be of Aboriginal origin. ${ }^{3132}$ Thirdly, small sized rooming and lodging houses operating without a licence might have been misclassified by the census as private rather than collective dwellings, so their residents would not have been included in any of our marginal housing categories. Fourthly,
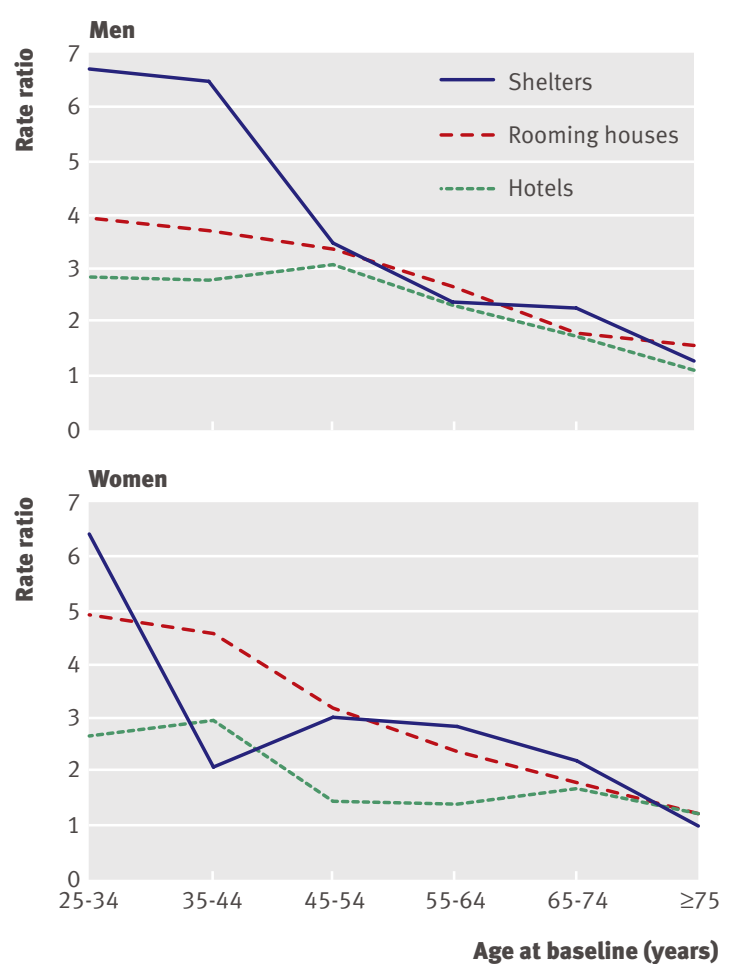

Fig $4 \mid$ Mortality rate ratios for men and women living in shelters, rooming houses, and hotels compared with entire cohort 


\section{WHAT IS ALREADY KNOWN ON THIS TOPIC}

Previous research on mortality among people living in housing situations consistent with severe disadvantage has focused primarily on homeless people, usually in a single city

There is a high level of excess mortality among the homeless compared with the general population

\section{WHAT THIS STUDY ADDS}

Living in shelters, rooming houses, and hotels is a marker for much higher mortality than would have been expected on the basis of low income alone

Even in a country with universal medical insurance, mortality from medically amenable causes of death is higher in both relative and absolute terms men and women whose usual place of residence was a hotel, motel, or tourist home mainly included people living in low cost accommodation that serves disadvantaged populations but also included a small number of people with much higher incomes who choose to live in hotels that provide amenities for long term residents. The presence of the latter group would be expected to slightly decrease the level of observed mortality within this category of housing. Fifthly, the socioeconomic and housing situation of cohort members was determined only at baseline, and no information was available on transitions into or out of different categories of housing or socioeconomic situations during the followup period. Finally, for the sake of simplicity, we determined mortality rates by income fifth using everyone in the study cohort. If people living in shelters, rooming houses, and hotels were to be excluded in calculations of mortality rates in the poorest income fifth, the mortality differences between these two groups (as shown in figs 1, 2, and 3) would be even greater. The magnitude of this effect, however, would be slight, as people living in shelters, rooming houses, and hotels account for less than $2 \%$ of the poorest income fifth.

\section{Conclusion}

In conclusion, this large national cohort study shows that homeless and marginally housed people living in shelters, rooming houses, and hotels have much higher mortality and shorter life expectancy than could be expected on the basis of low income alone. Mortality from medically amenable causes of death was higher in both relative and absolute terms. These findings emphasise the importance of considering housing situation as a marker of socioeconomic disadvantage. Further work should evaluate interventions to improve the health of homeless and marginally housed individuals, including interventions that improve housing affordability and quality.

Contributors: RW and MT conceived the study and conducted the analyses after revisions suggested by the other authors. SWH and RW drafted the manuscript with input from the other coauthors. All authors contributed in critically revising the article for important intellectual content, and approved the version submitted for publication. All authors had full access to the data (including statistical reports and tables) in the study and can take responsibility for the integrity of the data and the accuracy of the data analysis. SWH and RW are guarantors.
Funding: The Canadian census mortality follow-up study was funded by the Canadian Population Health Initiative, part of the Canadian Institute for Health Information. The Centre for Research on Inner City Health gratefully acknowledges the support of the Ontario Ministry of Health and Long-Term Care. JRD was supported by a Canadian Institutes of Health Research and Public Health Agency of Canada Chair in Applied Public Health. The authors' work was independent of the funders. The views expressed in this article are those of the authors and do not necessarily reflect the views of the above-named organizations or of the institutions with which they are affiliated.

Competing interests: None declared.

Ethical approval: The Canadian census mortality follow-up study, of which this study is a part, was approved by the Statistics Canada Policy Committee and the research ethics committee of the University of Toronto. Data sharing: No additional available.

1 Davey Smith G, ed. Health inequalities: lifecourse approaches. Policy Press, 2003.

2 Lantz PM, House JS, Lepkowski JM, Williams DR, Mero RP, Chen J. Socioeconomic factors, health behaviors, and mortality: results from a nationally representative prospective study of US adults. JAMA 1998;279:1703-8.

3 Hwang SW. Homelessness and health. CMAI 2001;164:229-33.

4 Hwang SW, Martin RE, Tolomiczenko GS, Hulchanski JD. The relationship between housing conditions and health status of rooming house residents in Toronto. Can J Public Health 2003;94:436-40.

5 Canadian Mortgage Housing Corporation. Research highlight: profile of rooming house residents. 2006. www.cmhc-schl.gc.ca/odpub/ pdf/65235.pdf.

6 Hibbs JR, Benner L, Klugman L, Spencer R, Macchin I, Mellinger A, et al. Mortality in a cohort of homeless adults in Philadelphia. N Engl Med 1994;331:304-9.

7 Hwang SW, Orav EJ, O'Connell JJ, Lebow JM, Brennan TA. Causes of death in homeless adults in Boston. Ann Intern Med 1997;126:625-8.

8 Barrow SM, Herman DB, Córdova P, Struening EL. Mortality among homeless shelter residents in New York City. Am J Public Health 1999;89:529-34.

9 Nordentoft M, Wandall-Holm N. 10 year follow up study of mortality among users of hostels for homeless people in Copenhagen. $B M$ J 2003;327:81.

10 Beijer U, Andréasson A, Agren G, Fugelstad A. Mortality, mental disorders and addiction: a 5-year follow-up of 82 homeless men in Stockholm. Nord J Psychiatry 2007;61:363-8.

11 Hwang SW. Mortality among men using homeless shelters in Toronto, Ontario. JAMA 2000;283:2152-7.

12 Cheung AM, Hwang SW. Risk of death among homeless women: a cohort study and review of the literature. CMA/ 2004;170:1243-7.

13 Roy E, Haley N, Leclerc P, Sochanski B, Boudreau JF, Boivin JF. Mortality in a cohort of street youth in Montreal. JAMA 2004;292:569-74.

14 Riley ED, Bangsberg DR, Guzman D, Perry S, Moss AR. Antiretroviral therapy, hepatitis C virus, and AIDS mortality among San Francisco's homeless and marginally housed. J Acquir Immune Defici Syndr 2005;38:191-5.

15 Babidge NC, Buhrich N, Butler T. Mortality among homeless people with schizophrenia in Sydney, Australia: a 10-year follow-up. Acta Psychiatr Scand 2001;103:105-10.

16 Kasprow WJ, Rosenheck R. Mortality among homeless and nonhomeless mentally ill veterans. J Nerv Ment Dis 2000;188:141-7.

17 Wilkins R, Tjepkema M, Mustard C, Choinière R. The Canadian census mortality follow-up study, 1991 through 2001. Health Rep 2008;19:25-43.

18 Fair M. Generalized record linkage system-Statistics Canada's record linkage software. Austrian J Stat 2004;33:37-53.

19 Fair ME, Carpenter M, Aylwin H. Occupational and environmental health research projects: a descriptive catalogue 1978 to 2005. Statistics Canada; 2006

20 Mackenbach JP, Stirbu I, Roskam AJ, Schaap MM, Menvielle G, Leinsalu $M$, et al. Socioeconomic inequalities in health in 22 European countries. N Engl J Med 2008;358:2468-81.

21 Office of National Statistics. Deaths related to drug poisoning: England and Wales, 1999-2003. Health Stat Q 2005; Spring:52-9.

22 Carrière KC, Roos L. A method of comparison for standardized rates of low-incidence events. Med Care 1997;35:57-69.

23 Chiang CL. The life table and its applications. Robert E Krieger, 1984.

24 Bourbeau R, Légaré J, Émond V. New birth cohort life tables for Canada and Quebec, 1801-1991. Statistics Canada, 1997.

25 Nagnur D. Longevity and historical life tables 1921-1981 (abridged). Canada and the provinces. Supply and Services Canada, 1986 
26 Shaw M, Dorling D, Brimblecombe N. Life chances in Britain by housing wealth and for the homeless and vulnerably housed. Environ Plan A 1999;31:2239-48.

27 Tsemberis S, Eisenberg RF. Pathways to housing: supported housing for street-dwelling homeless individuals with psychiatric disabilities. Psychiatr Serv 2000;51:487-93.

28 Hwang SW, Tolomiczenko G, Kouyoumdjian FG, Garner RE. Interventions to improve the health of the homeless: a systematic review. Am J Prev Med 2005;29:311-9.

29 Statistics Canada. Coverage. Minister of Industry, Science and Technology, 1994.
30 Shaw M, Dorling D. Mortality among street youth in the UK. Lancet 1998;352:743.

31 Golden A, Currie WH, Greaves E, Latimer EJ. Report of the Mayor's Homelessness Action Task Force. Taking responsibility for homelessness: an action plan for Toronto. 1999. www.toronto.ca/ pdf/homeless_action.pdf.

32 Homelessness Count Committee. A count of homeless persons in Edmonton. 2000. http://intraspec.ca/

Edmonton_homeless_sept00.pdf.

Accepted: 8 June 2009 